\title{
原著
}

\section{慢性透析患者の地域差の要因 一日本透析医学会統計調查委員会研究一}

\author{
尾 形 聡* 西 慎 - 若 井 建 志* 井関 邦 敏 \\ 椿 原 美 治 \\ 日本透析医学会統計調査委員会・統計解析小委員会*
}

キーワード : 慢性腎不全, 都道府県, 導入率, 生存率, 透析専門医

〈要旨〉

慢性透析患者においてその導入率，生存率などには，地域差があることが知られている．今回われわれは，その 要因について検討した. 日本透析医学会 2004 2006 年末の統計調査データベース (JRDR-09105) ( $n=102,011) を$ 基に, 人口あたり透析導入率と透析導入後 1 年生存率（ともに年齢を調整）を算出した. 一方, 日本透析医学会 · 日本腎臓学会ホームページ・施設会員名簿, 財務省統計局, 国民栄養調査などから 122 項目の都道府県別データを 抽出し, 単回帰分析で透析導入率, 透析導入後 1 年生存率, 透析専門医数との関連を検討した. 結果, 透析導入率 では, 透析施設数, 夜間透析施設数, 透析専門医数, 一般病院数, 一般病院平均在院日数, 年平均気温, 最低気温, 日照時間，高齢単身世帯割合，肉類摂取量，脂質エネルギーが男女ともに正の相関を認め，一般老年人口割合，降 水日数, 雪日数, 一般世帯の平均人員, 悪性新生物 - 脳血管疾患による死亡者数, 緑黄色野菜以外の野菜・魚介類 · 炭水化物・カルシウム・鉄・食塩・ビタミン $\mathrm{B}_{2} \cdot \mathrm{C}$ 摂取量が男女ともに負の相関を認めた. 透析導入後 1 年生存率 では, 脳出血の既往が男女ともに正の相関を, 透析後 BUN が男女ともに負の相関を認めた. また専従看護師, 専従 栄養士数が正の相関を認めた. 透析専門医数では, 透析導入患者数, 1 年生存率, 蛋白異化率, $\mathrm{Kt} / \mathrm{V}, 1$ 回あたり透 析時間, 透析施設数, 夜間透析施設数で正の相関を認め, 透析後 $\mathrm{Cr}$ が負の相関を認めた. 透析患者の導入率, 生存 率, 透析専門医数にはさまざまな因子が関与しており, 今後の透析医療をいかに進めていくかは多角的な方面から の検討が必要である.

\section{Factors influencing regional differences in the outcome of dialysis in Japan}

Satoshi Ogata*, Sinichi Nishi, Kenji Wakai*, Kunitoshi Iseki and Yoshiharu Tsubakihara The Committee of Renal Data Registry, the Japanese Society for Dialysis Therapy

Key words : chronic renal failure, incidence, survival rate, dialysis specialist, ecological study

〈Abstract〉

There are regional differences in the outcome of dialysis ; however, few studies have investigated the causes. We stratified 122 factors by gender and by 47 prefectures and then investigated which factors are associated with regional differences in the incidence of dialysis treatment, the survival of dialysis patients, and the number of specialists by univariate analysis. The database used was JRDR-09105 maintained by the Japanese Society for Dialysis Therapy. This database includes 102,011 patients starting dialysis in Japan during 2004-06. The number of daytime/night dialysis institutes, the number of specialists, the number of hospitals, the average duration of hospitalization, the average annual temperature, the lowest temperature, total hours of sunshine, the percentage of elderly people living alone, the interval between the first hospital consultation and initiation of dialysis, intake of meat, dietary fat intake, (positive correlation), general population over 65 years old, days of rain, duration of the snow season, the number of family members, mortality rate from malignant tumors, cerebrovascular disease, and many nutritional factors (negative) were associated with the incidence. A history of brain hemorrhage (positive)

尾形 聡 広島国際大学保健医療学部 $\quad$ \% 739-2695 広島県東広島市黒瀬学園台 555-36

Satoshi Ogata Tel : 0823-70-4643 Fax : 0823-70-4542

〔受付日：2011 年 2 月 6 日, 受理日：2011 年 5 月 31 日〕 
and blood urea nitrogen after dialysis (negative) were correlated with the 1-year survival rate in both genders. Numbers of full-time nurses and dietitians were also correlated with 1-year survival rate (positive). The number of dialysis specialists was associated with the incidence of dialysis, 1-year survival, protein catabolic rate, Kt/V, dialysis time, number of daytime/night dialysis institutions (positive), and blood creatinine after dialysis (negative). Many factors, including the number of dialysis specialists, were associated with the incidence of dialysis and with survival.

\section{緒言}

慢性透析患者の成績には，地域差や人種差が存在す る。米国に扔いては透析の導入率に地域差が認めら れ，アジア人の透析導入率は白人よりも高く予後がよ いことなどが知られている ${ }^{1,2)}$. 標高 6,000 フィート 以上の標高の高い地域に住んでいる慢性透析患者は貧 血によるエリスロポエチン製剤の消費量が少なく予後 がよいことも示されている 国内，八ワイ在住日系人，米国本土在住日系慢性透析 患者を比較し，導入原疾患，導入時年齢，死因などに 差があることを示した2)。この結果は同じ人種でも住 んでいる地域や食習慣など環境が異なれば，慢性透析 患者の成績も異なることを示す，日本国内においても 透析導入率や生命予後が異なることが近年示され，そ の原因についてさまざまな分析がなされつつある わが国に㧍いては，(社) 日本透析医学会が毎年末に全 慢性透析患者を対象とした調査を行い，98\%以上の高 い回収率を得ている ${ }^{9)}$. 透析導入率や生命予後の地域 差を解消することで透析医療を改善できる余地を探る ことを目的として，今回われわれはこの調査結果を用 い, 日本国内における地域差の原因を検索し検討した.

\section{I. 方 法}

都道府県別透析導入率は，日本透析医学会 2004 2006 年末の統計調查データベース（JRDR-09105）か ら 3 年間の新規透析導入患者を抽出し $(\mathrm{n}=102,011)$, 単位人口あたりの年間平均透析導入率を都道府県別男 女別に算出し， 2005 年の国勢調査結果 ${ }^{10)} も と に 5$ 歳 年齢ごとの一般人口年齢構成で補正を行った． 1 年生 存率は, JRDR-09105 から都道府県別男女別に算出し, 透析導入時の年齢で補正を行った。データベースは単 年度ごとの横断データであり各患者の平均観察期間が 6 か月となるため, 1 年生存率は各年末の生存の有無 からその死亡数を 2 倍し算出した.

検討する項目は, JRDR-09105, 日本透析医学会ホー ムページ ${ }^{11)}$ ，日本透析医学会施設会員名簿（2006 年度
版 $)^{12)} ， 1995 \sim 1999$ 年の国民栄養調查から都道府県別 の食品群別，栄養素別摄取量 ${ }^{111}$, 財務省統計局の 2004 2006 年の間の都道府県別データ ${ }^{14)}$ から抽出し た合計 122 項目で，これらを説明変数とし，透析導入 率と 1 年生存率を目的変数とし, 単回帰分析を行い, $\mathrm{p}<0.05$ を有意とした.

また，単位人口あたりの透析専門医数と各種因子， 透析後血中尿素窒素 $(\mathrm{BUN})$ と $\mathrm{Kt} / \mathrm{V}$ との関係も検討 した.

解析は統計ソフト JMP for Windows, version 8.0 （SAS Institute，Cary，NC，USA）を使用した.

\section{II. 結 果}

47 都道府県の年齢補正後平均透析導入率は人口 100 万人あたり年間 $265.6 \pm 38.9$ 人（最小值男性 228.1 女性 127.3 最大值 男性 457.1 女性 322.2), 1 年生存 率は $0.832 \pm 0.027$ (最小值 男性 0.740 女性 0.742 最 大值男性 0.897 女性 0.908$)$ ，透析専門医数は人口 100 万人あたり $30.8 \pm 11.8$ 人（最小值 11.1 最大值 58.0) であった（1 年生存率は平均観察期間が 6 か月 であるため実際の 1 年生存率とは異なる).

透析導入率では, 検討した 81 項目のうち, 男女いず れか 42 項目で有意な相関を認めた，男女によってそ の項目は異なり，女性は男性よりも栄養調查項目で有 意な相関を示す項目が多く認められた，男女ともに正 の相関を認めたもの，すなわち都道府県別透析導入率 を上げている因子は，透析施設数，夜間透析施設数， 透析専門医数, 一般病院数, 一般病院平均在院日数, 年平均気温, 最低気温, 日照時間, 高齢単身世带割合, 肉類摂取量，脂質エネルギー比であった，男女ともに 負の相関を認めたもの，すなわち都道府県別透析導入 率を下げている因子は, 一般老年人口割合, 降水日数, 雪日数, 一般世帯の平均人員, 悪性新生物・脳血管疾 患による死亡者数, 緑黄色野菜以外の野菜 - 魚介類 炭水化物・カルシウム・鉄・食塩・ビタミン $\mathrm{B}_{2} \cdot \mathrm{C}$ 摂 取量であった（表 1).

透析導入後 1 年生存率では, 検討した 97 項目のう ち，男女いずれか 22 項目で有意な相関を認めた。透 
表 1 年齢調整人口 100 万人あたり都道府県別透析導入患者数（2004～2006 年）との関係

\begin{tabular}{|c|c|c|c|c|c|c|c|}
\hline & & & & & & & \\
\hline & 単位 & 平均值 & 土標準偏差 & $\mathrm{r}$ 值 & $\mathrm{p}$ 值 & $\mathrm{r}$ 値 & $\mathrm{p}$ 值 \\
\hline 心筋梗塞の既往 & $\%$ & 男 $7.29 \pm 1.78$ & 女 $4.80 \pm 1.75$ & 0.048 & 0.748 & 0.410 & $0.004^{* *}$ \\
\hline 脳出血の既往 & $\%$ & 男 $2.96 \pm 0.82$ & 女 $2.86 \pm 1.10$ & 0.016 & 0.906 & 0.123 & 0.407 \\
\hline 脳梗塞の既往 & $\%$ & 男 $14.3 \pm 2.7$ & 女 $10.7 \pm 2.4$ & 0.068 & 0.651 & 0.281 & 0.056 \\
\hline 四肢切断の既往 & $\%$ & 男 $2.13 \pm 0.67$ & 女 $1.02 \pm 0.59$ & 0.427 & $0.003^{* *}$ & 0.233 & 0.114 \\
\hline 導入病院初診期間 & か月 & 男 $18.6 \pm 9.0$ & 女 $19.4 \pm 8.2$ & -0.375 & $0.009^{* *}$ & 0.263 & 0.074 \\
\hline 導入時 eGFR & $\mathrm{mL} / \mathrm{min}$ & 男 $5.75 \pm 0.64$ & 女 $5.11 \pm 0.67$ & 0.059 & 0.693 & -0.052 & 0.287 \\
\hline 導入時臨床症状点数 & 点 & 男 $17.5 \pm 2.5$ & 女 $18.0 \pm 2.8$ & -0.129 & 0.387 & -0.034 & 0.818 \\
\hline 導入時日常生活障害度点数 & 点 & 男 $17.2 \pm 1.4$ & 女 $17.7 \pm 1.8$ & 0.073 & 0.626 & 0.036 & 0.808 \\
\hline 旧 厚生省研究班透析導入基準点数 & 点 & 男 $67.0 \pm 3.5$ & 女 $66.1 \pm 3.8$ & 0.038 & 0.802 & -0.196 & 0.186 \\
\hline 導入原疾患（糖尿病率） & & 男 $0.336 \pm 0.053$ & 女 $0.271 \pm 0.054$ & 0.268 & 0.069 & 0.100 & 0.505 \\
\hline 初回透析アクセス内シャント & 己血管使用率 & 男 $0.877 \pm 0.048$ & 女 $0.824 \pm 0.068$ & 0.104 & 0.488 & -0.104 & 0.486 \\
\hline 透析施設数 & / 人口 100 万人 & 30.0 & \pm 6.8 & 0.407 & $0.005^{* *}$ & 0.441 & $0.002^{* *}$ \\
\hline 病院/診療所比（透析施設） & & 1.83 & \pm 0.95 & 0.304 & $0.038^{*}$ & 0.274 & 0.062 \\
\hline 夜間透析施設数 & /人口 100 万人 & 15.9 & \pm 4.6 & 0.336 & $0.021^{*}$ & 0.372 & $0.010^{*}$ \\
\hline 夜間透析施設数/全施設数比 & & 0.533 & \pm 0.099 & -0.017 & 0.909 & 0.005 & 0.973 \\
\hline 透析専門医数 & 人/人口 100 万人 & 30.8 & \pm 11.8 & 0.513 & $<0.001^{* * *}$ & 0.436 & $0.002^{* *}$ \\
\hline 総人口 & 万人 & 272 & \pm 260 & 0.053 & 0.725 & 0.028 & 0.851 \\
\hline 人口密度 & 人/ $\mathrm{km}^{2}$ (可住地面積) & 1372 & \pm 1678 & 0.066 & 0.660 & 0.074 & 0.622 \\
\hline 一般老年人口割合 & & 0.218 & \pm 0.028 & -0.290 & $0.048^{*}$ & -0.288 & $0.048^{*}$ \\
\hline 可住地面積 & $\mathrm{km}^{2}$ & 2583 & \pm 3042 & 0.083 & 0.579 & -0.039 & 0.796 \\
\hline 人口増加率 & & -0.25 & \pm 0.40 & 0.213 & 0.151 & 0.235 & 0.111 \\
\hline 年平均気温 & ${ }^{\circ} \mathrm{C}$ & 15.2 & \pm 2.4 & 0.413 & $0.004^{* *}$ & 0.597 & $<0.001^{* * *}$ \\
\hline 最高気温 & ${ }^{\circ} \mathrm{C}$ & 31.7 & \pm 1.2 & 0.183 & 0.218 & 0.245 & 0.097 \\
\hline 最低気温 & ${ }^{\circ} \mathrm{C}$ & 0.3 & \pm 3.2 & 0.308 & $0.035^{*}$ & 0.308 & $<0.001^{* * *}$ \\
\hline 年平均相対湿度 & $\%$ & 67.5 & \pm 4.7 & -0.368 & $0.011^{*}$ & -0.221 & 0.135 \\
\hline 日照時間 & 時間/年 & 1925 & \pm 241 & 0.484 & $<0.001^{* * *}$ & 0.318 & $0.030^{*}$ \\
\hline 降水量 & $\mathrm{mm} /$ 年 & 1388 & \pm 500 & -0.145 & 0.332 & 0.003 & 0.986 \\
\hline 快晴日数 & 日/年 & 23.3 & \pm 14.4 & 0.317 & $0.030^{*}$ & 0.204 & 0.169 \\
\hline 降水日数 & 日/年 & 113 & \pm 37 & -0.494 & $<0.001^{* * *}$ & -0.388 & $0.007^{* *}$ \\
\hline 雪日数 & 日/年 & 36.1 & \pm 32.9 & -0.428 & $0.003^{* *}$ & -0.477 & $<0.001^{* * *}$ \\
\hline 粗出生率 & 人/人口千人 & 8.26 & \pm 0.74 & 0.284 & 0.0529 & 0.536 & $<0.001^{* * *}$ \\
\hline 粗死亡率 & 人/人口千人 & 男 $10.27 \pm 1.50$ & 女 $8.04 \pm 1.19$ & -0.217 & 0.143 & -0.232 & 0.117 \\
\hline 年齢調整死亡率 & 人/人口千人 & 男 $5.98 \pm 0.34$ & 女 $2.96 \pm 0.13$ & 0.111 & 0.459 & 0.202 & 0.172 \\
\hline 一般世帯の平均人員 & 人 & 2.67 & \pm 0.20 & -0.455 & $0.001^{* *}$ & -0.417 & $0.004^{* *}$ \\
\hline 高齢夫婦のみの世帯割合 & \%（対一般世帯） & 9.17 & \pm 1.56 & 0.028 & 0.853 & 0.031 & 0.837 \\
\hline 高齢単身世帯の割合 & \% (対一般世帯) & 8.13 & \pm 1.90 & 0.270 & 0.066 & 0.340 & $0.019^{*}$ \\
\hline 標準化死亡率 & 人/人口千人 & 2.15 & \pm 0.11 & 0.252 & 0.088 & 0.227 & 0.125 \\
\hline 平均余命（0 歳） & 年 & 男 $78.64 \pm 0.66$ & 女 $85.84 \pm 0.45$ & 0.159 & 0.285 & 0.056 & 0.707 \\
\hline 平均余命（65 歳） & 年 & 男 $18.31 \pm 0.37$ & 女 $23.50 \pm 0.40$ & -0.009 & 0.950 & 0.217 & 0.144 \\
\hline 生活習慣病による死亡者数 & 人/人口 10 万人 & 561 & \pm 76 & -0.281 & 0.056 & -0.332 & $0.023^{*}$ \\
\hline 悪性新生物による死亡者数 & 人/人口 10 万人 & 274 & \pm 32 & -0.328 & $0.024^{*}$ & -0.343 & $0.018^{*}$ \\
\hline 糖尿病による死亡者数 & 人/人口 10 万人 & 11.5 & \pm 1.9 & 0.201 & 0.176 & 0.079 & 0.596 \\
\hline 高血圧による死亡者数 & 人/人口 10 万人 & 4.9 & \pm 1.4 & -0.016 & 0.914 & -0.102 & 0.495 \\
\hline 心疾患による死亡者数 & 人/人口 10 万人 & 152 & \pm 24 & -0.134 & 0.370 & -0.202 & 0.173 \\
\hline 脳血管疾患による死亡者数 & 人/人口 10 万人 & 119 & \pm 25 & -0.317 & $0.030^{*}$ & -0.372 & $0.010 * *$ \\
\hline 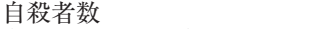 & 人/人口 10 万人 & 25.4 & \pm 4.3 & -0.271 & 0.066 & -0.166 & 0.263 \\
\hline （県民一人あたり）県民所得 & 千円/年 & 2752 & \pm 455 & -0.056 & 0.705 & -0.231 & 0.119 \\
\hline 一世帯あたり実収入 & 千円/月 & 528 & \pm 73 & -0.165 & 0.266 & -0.365 & $0.012^{*}$ \\
\hline 一世帯あたり貯蓄現在高 & 万円 & 1483 & \pm 301 & -0.263 & 0.074 & -0.439 & $0.020^{*}$ \\
\hline 一般病院数 & /人口 10 万人 & 7.3 & \pm 2.8 & 0.391 & $0.007^{* *}$ & 0.358 & $0.014^{*}$ \\
\hline 一般診療所数 & /人口 10 万人 & 76.7 & \pm 12.4 & 0.020 & 0.896 & -0.057 & 0.703 \\
\hline 一般病院病床数 & /人口 10 万人 & 1192 & \pm 280 & 0.246 & 0.095 & 0.256 & 0.082 \\
\hline 医師数 & 人/人口 10 万人 & 208 & \pm 35 & 0.235 & 0.111 & 0.161 & 0.279 \\
\hline 看護師数 & 人/人口 10 万人 & 894 & \pm 211 & 0.235 & 0.112 & 0.266 & 0.070 \\
\hline 一般病院平均在院日数 & 日 & 31.5 & \pm 5.6 & 0.359 & $0.013^{*}$ & 0.323 & $0.027^{*}$ \\
\hline 健康診断受診率 & $\%$ & 22.1 & \pm 18.3 & -0.024 & 0.875 & -0.130 & 0.382 \\
\hline 人口一人あたり社会福祉費 & 千円 & 38.3 & \pm 6.8 & 0.116 & 0.436 & 0.237 & 0.108 \\
\hline 米類 & $\mathrm{g} /$ 日 & 男 $217.9 \pm 14.8$ & 女 $150.4 \pm 11.5$ & -0.317 & $0.030^{*}$ & -0.178 & 0.231 \\
\hline いも類 & $\mathrm{g} /$ 日 & 男 $67.1 \pm 9.1$ & 女 $66.8 \pm 8.9$ & -0.156 & 0.294 & -0.403 & $0.005^{* *}$ \\
\hline 豆類 & $\mathrm{g} /$ 日 & 男 $80.2 \pm 9.4$ & 女 $72.9 \pm 9.1$ & -0.259 & 0.079 & -0.248 & 0.092 \\
\hline 果物類 & $\mathrm{g} /$ 日 & 男 $96.1 \pm 12.9$ & 女 $134.5 \pm 18.2$ & -0.081 & 0.589 & -0.468 & $<0.001^{* * *}$ \\
\hline 緑黄色野菜 & $\mathrm{g} /$ 日 & 男 $94.9 \pm 8.5$ & 女 $95.8 \pm 10.4$ & -0.205 & 0.168 & -0.245 & 0.097 \\
\hline その他の野菜 & $\mathrm{g} /$ 日 & 男 $217.3 \pm 22.7$ & 女 $205.0 \pm 24.4$ & -0.361 & $0.013^{*}$ & -0.454 & $0.001^{* *}$ \\
\hline 魚介類 ～～～～～～～ & $\mathrm{g} /$ 日 & 男 $119.4 \pm 12.6$ & 女 $95.4 \pm 9.7$ & -0.349 & $0.008^{* *}$ & -0.418 & $0.003^{* *}$ \\
\hline 肉類 & $\mathrm{g} /$ 日 & 男 $93.2 \pm 10.7$ & 女 $70.1 \pm 8.0$ & 0.425 & $0.003^{* *}$ & 0.597 & $<0.001^{* * *}$ \\
\hline 卵類 & $\mathrm{g} /$ 日 & 男 $47.4 \pm 4.1$ & 女 $39.8 \pm 3.9$ & -0.011 & 0.940 & -0.122 & 0.413 \\
\hline 牛乳·乳製品 & $\mathrm{g} /$ 日 & 男 $87.3 \pm 11.3$ & 女 $113.6 \pm 12.7$ & -0.199 & 0.179 & -0.419 & $0.003^{* *}$ \\
\hline エネルギー & $\mathrm{kcal} /$ 日 & 男 $2285 \pm 63$ & 女 $1858 \pm 45$ & -0.203 & 0.170 & -0.543 & $<0.001^{* * *}$ \\
\hline タンパク質 & $\mathrm{g} / \mathrm{B}$ & 男 $90.8 \pm 2.7$ & 女 $75.8 \pm 2.2$ & -0.195 & 0.187 & -0.463 & $0.001^{* *}$ \\
\hline 動物性タンパク質 & $\mathrm{g} /$ 日 & 男 $49.3 \pm 2.2$ & 女 $40.4 \pm 1.7$ & 0.066 & 0.661 & -0.002 & 0.990 \\
\hline 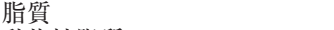 & $\mathrm{g} /$ 日 & 男 $62.7 \pm 3.1$ & 女 $55.4 \pm 2.2$ & 0.175 & 0.241 & 0.030 & 0.841 \\
\hline 動物性脂質 & $\mathrm{g} /$ 日 & 男 $31.7 \pm 1.6$ & 女 $26.8 \pm 1.3$ & 0.277 & 0.060 & 0.192 & 0.195 \\
\hline 脂質エネルギー比 & $\%$ & 男 $25.9 \pm 1.0$ & 女 $26.9 \pm 1.1$ & 0.350 & $0.016^{*}$ & 0.462 & $0.001^{* *}$ \\
\hline 炭水化物 & $\mathrm{g} /$ 日 & 男 $30.7 \pm 1.0$ & 女 $258 \pm 9$ & -0.298 & $0.042^{*}$ & -0.634 & $<0.001^{* * *}$ \\
\hline カルシウム & $\mathrm{mg} /$ 日 & 男 $552 \pm 25$ & 女 $550 \pm 33$ & -0.343 & $0.018^{*}$ & -0.602 & $<0.001^{* * *}$ \\
\hline 鉄 & $\mathrm{mg} /$ 日 & 男 $12.7 \pm 0.5$ & 女 $11.3 \pm 0.6$ & -0.416 & $0.004^{* *}$ & -0.630 & $<0.001^{* * *}$ \\
\hline 食塩 ～～～～～～ & g/日 & 男 $14.3 \pm 0.9$ & 女 $12.7 \pm 1.0$ & -0.414 & $0.004^{* *}$ & -0.581 & $<0.001^{* * *}$ \\
\hline ビタミン A & IU/日 & 男 $2697 \pm 254$ & 女 $2588 \pm 245$ & 0.077 & 0.606 & -0.069 & 0.644 \\
\hline ビタミン $\mathrm{B}_{1}$ & $\mathrm{mg} /$ 日 & 男 $1.28 \pm 0.05$ & 女 $1.12 \pm 0.05$ & -0.035 & 0.814 & -0.435 & $0.002^{* *}$ \\
\hline ビタミン $\mathrm{B}_{2}$ & $\mathrm{mg} /$ 日 & 男 $1.49 \pm 0.06$ & 女 $1.34 \pm 0.07$ & -0.346 & $0.017^{*}$ & -0.534 & $<0.001^{* * *}$ \\
\hline ビタミン C & $\mathrm{mg} /$ 日 & 男 $122 \pm 10$ & 女 $132 \pm 14$ & -0.356 & $0.014^{*}$ & -0.596 & $<0.001^{* * *}$ \\
\hline
\end{tabular}


析導入率と同様に男女によってその項目は異なり, 男 性は女性よりも透析処方や透析施設環境で有意な相関 を示す項目が多く認められた，男女ともに正の相関を 認めたもの，すなわち生存率を上げている因子は，脳 出血の既往であった，男女ともに負の相関を認めたも の, すなわち生存率を下げている因子は透析後 BUN であった（表 2)。また，男女全体での透析後 BUN と $\mathrm{Kt} / \mathrm{V}$ とは非常に強い負の相関を認めた $(\mathrm{r}=-0.902$, $\mathrm{p}<0.001)$.

人口 100 万人あたりの透析専門医数では, 検討した 39 項目のうち， 8 項目の有意な相関を認めた．正の相 関を認めたのは, 透析導入患者数, 1 年生存率, 蛋白異 化率, $\mathrm{Kt} / \mathrm{V}, 1$ 回あたり透析時間, 透析施設数, 夜間 透析施設数であった，負の相関を認めたのは，透析後 クレアチニン $(\mathrm{Cr})$ であった（表 3 ).

\section{III. 考 察}

今回のわれわれの検討では, 透析導入率, 1 年生存 率の都道府県地域差にはさまざまな因子との相関を認 めた．また，透析専門医数はさまざまな因子の地域差 に関連を認めた。

透析導入率は, 多くの項目で有意な相関を認めた. 四肢切断や心筋梗塞の既往が多い都道府県では透析導 入率が高く, 動脈硬化が腎疾患に関与するという意味 で臨床的に納得のできる結果である。初診から透析導 入までの期間が長い都道府県で透析導入率が低いこと は, 医療介入により透析導入が回避, 遷延させること ができていることを示す，透析施設数，夜間施設数， 透析専門医師数, 一般病院数とも正の相関を認めるが, これらは患者の多い都道府県ではその割合に応じて施 設整備が行われていると解釈できる。気象条件におい ては，気温が高く，天気が良い都道府県で透析導入率 が高く, 雨や雪日数が多い都道府県で低く, 気象条件 が透析導入率に影響を与えている可能性は否定できな い. また，高齢単身世带で透析導入率が高く，一般世 带の平均人員が多く, 実収入や貯蓄残高が高い都道府 県で透析導入率が低いことは，家族構成や経済的な素 因が腎疾患に影響を与えている可能性がある。また, 逆に腎疾患に䍜患したため, 医療費, 通院費, 就職状 況などの問題から経済的に困窮してしまう可能性も考 えられる. 肉類や脂質エネルギー比が高い地域で透析 導入率が高く, 米類, 魚介類などの摂取量が多い都道 府県で低いことは，食事も透析導入率に影響を与える 重要な要素であることがいえる．塩分摂取量が多い都 道府県で透析導入率が低いという結果については, 塩
分摂取量が肉類以外の食品摂取量と正の相関を示し, 食品添加物としてこれらの食品に食塩が多く使用され ているための交絡の可能性があることをすでに報告し $た^{8)}$. 生活習慣病・悪性新生物・脳血管疾患による死 亡率が高い地域で透析導入率が低いことは，透析導入 前にこれらの疾患による死亡率が高くなっている可能 性やこれらの疾患による非導入の可能性がある。この ように透析導入率の地域差には, 気候や社会・経済的 な要因など医療の介入の余地がないものも数多く関与 していると考えられた。また，女性は男性よりも栄養 調査項目で有意な相関を示す項目が多く, 女性は男性 よりも食事の影響を受けやすいという可能性がある が，女性の方が栄養調查の精度が高い可能性も考えら れその解釈には注意が必要である。

1 年生存率に扔いても, 男女で様相が異なる。男性 ではアルブミン, 蛋白異化率, クレアチニン産生速度, 除水量, $\mathrm{Kt} / \mathrm{V}, 1$ 回あたり透析時間, 初回透析アクセ ス内シャント自己血管使用率など透析処方で有意な相 関を示す項目が多く, その他栄養状態・栄養摂取量を 示寸因子, 夜間透析施設数, 夜間透析施設/全透析施設 数比など施設整備に関するもので正の相関を, エリス ロポエチン使用週 9,000 単位以上, 透析後 BUN, 導入 時臨床症状点数で負の相関を示した。 女性では平均余 命で正の相関を、リン，一世帯あたり貯蓄現在高で負 の相関を認めた．男女とも脳出血の既往が正の相関を 示し, 脳出血の既往が高い地区で予後が良いという結 果であった。これについて日本透析医学会 ${ }^{15)}$ の報告で は, わが国の透析患者では透析開始時の血圧が高い群 で脳出血のリスクが高かったが，血圧が $140 〜 170$ $\mathrm{mmHg}$ の群で最も生命予後が良かったことから, 血 圧との交絡があると考えられる。一方, 表 1 では一般 人口の脳血管疾患による死亡者数と透析導入率との間 には負の相関を認めたが，これは一般人口の脳血管疾 患患者が透析導入前に死亡あるいは非導入となった可 能性を示すものである. 脳梗塞や脳出血の既往と透析 導入率には相関がなかったことも，これらの疾患の既 往のない患者が透析導入となった可能性がある，男女 とも透析後 BUN が負の相関を示したが, 透析後 BUN と $\mathrm{Kt} / \mathrm{V}$ との関係は非常に強い負の相関を認め, 透析 量が多い地域では透析後 BUN が低く 1 年生存率も高 かったと考えられる.このように透析患者の予後の地 域差には，栄養状態や透析処方の違いが関与している 可能性があり, 今後地域差の解消に改善の余地がある と考えられる。

透析スタッフとの関係では, 専従の看護師, 専従の 栄養士が多い都道府県で 1 年生存率が上昇していた。 
表 2 年齢調整都道府県別透析導入患者 1 年生存率（2004 2006 年）との関係

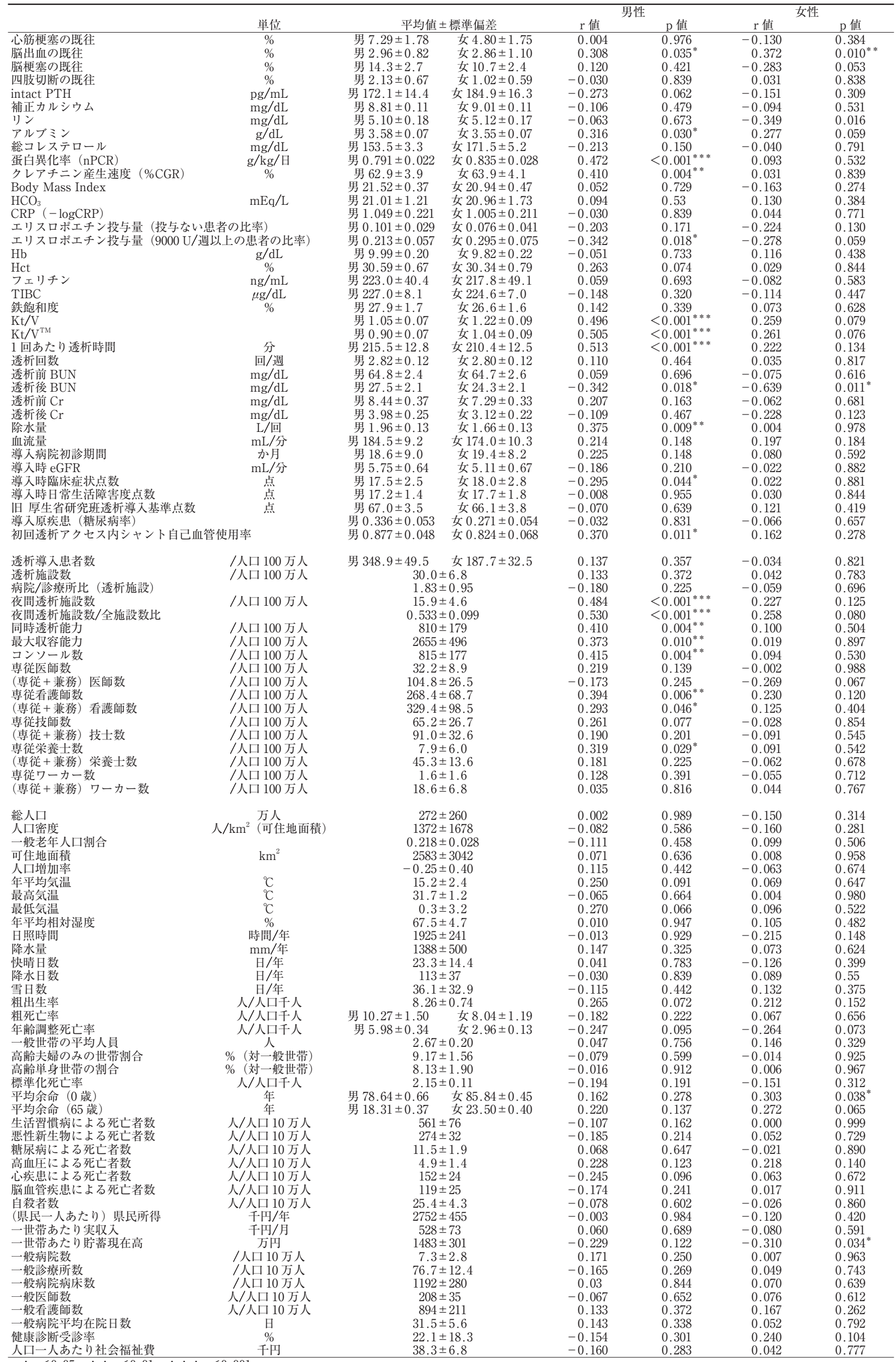


表 3 人口 100 万人あたり透析専門医数との関係

\begin{tabular}{|c|c|c|c|c|}
\hline & 単位 & 平均値 \pm 標準偏差 & $\mathrm{r}$ 值 & $\mathrm{p}$ 值 \\
\hline 透析導入患者数 & 人/人口 100 万人 & $265.6 \pm 38.9$ & 0.497 & $<0.001^{* * *}$ \\
\hline 透析導入後 1 年生存率 & & $0.881 \pm 0.022$ & 0.297 & $0.043^{*}$ \\
\hline 透析施設数 & /人口 100 万人 & $30.0 \pm 6.8$ & 0.631 & $<0.001^{* * *}$ \\
\hline 病院/診療所比（透析施設） & & $1.83 \pm 0.95$ & -0.055 & 0.710 \\
\hline 夜間透析施設数 & /人口 100 万人 & $15.9 \pm 4.6$ & 0.512 & $<0.001^{* * *}$ \\
\hline 夜間透析施設数/全施設数比 & & $0.533 \pm 0.099$ & -0.012 & 0.935 \\
\hline intact PTH & $\mathrm{pg} / \mathrm{mL}$ & $172.1 \pm 14.4$ & 0.105 & 0.482 \\
\hline 補正カルシウム & $\mathrm{mg} / \mathrm{dL}$ & $8.88 \pm 0.10$ & -0.021 & 0.886 \\
\hline 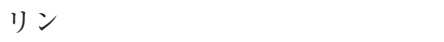 & $\mathrm{mg} / \mathrm{dL}$ & $5.11 \pm 0.16$ & -0.200 & 0.178 \\
\hline アルブミン & $\mathrm{g} / \mathrm{dL}$ & $3.57 \pm 0.06$ & -0.067 & 0.655 \\
\hline 総コレステロール & $\mathrm{mg} / \mathrm{dL}$ & $159.8 \pm 3.5$ & 0.168 & 0.259 \\
\hline 蛋白異化率（nPCR） & $\mathrm{g} / \mathrm{kg} /$ 日 & $0.807 \pm 0.023$ & 0.323 & $0.027^{*}$ \\
\hline クレアチニン産生速度（\% CGR） & $\%$ & $63.3 \pm 3.6$ & 0.15 & 0.315 \\
\hline Body Mass Index & & $21.31 \pm 0.38$ & -0.431 & 0.431 \\
\hline $\mathrm{HCO}_{3}$ & $\mathrm{mEq} / \mathrm{L}$ & $21.03 \pm 1.23$ & -0.009 & 0.951 \\
\hline $\mathrm{CRP}(-\log \mathrm{CRP})$ & & $1.017 \pm 0.152$ & 0.134 & 0.369 \\
\hline エリスロポエチン投与量（投与ない， & 比率） & $0.089 \pm 0.031$ & 0.008 & 0.956 \\
\hline エリスロポエチン投与量 $(9000 \mathrm{U} /$ 週 & 上の患者の比率) & $0.289 \pm 0.065$ & -0.186 & 0.211 \\
\hline $\mathrm{Hb}$ & $\mathrm{g} / \mathrm{dL}$ & $9.93 \pm 0.20$ & 0.020 & 0.893 \\
\hline Hct & $\%$ & $30.50 \pm 0.68$ & 0.123 & 0.412 \\
\hline フェリチン & $\mathrm{ng} / \mathrm{mL}$ & $224.8 \pm 37.7$ & 0.063 & 0.673 \\
\hline TIBC & $\mu \mathrm{g} / \mathrm{dL}$ & $226.3 \pm 6.8$ & -0.265 & 0.072 \\
\hline 鉄飽和度 & $\%$ & $27.4 \pm 1.4$ & 0.059 & 0.692 \\
\hline $\mathrm{Kt} / \mathrm{V}$ & & $0.95 \pm 0.08$ & 0.291 & $0.047^{*}$ \\
\hline 1 回あたり透析時間 & 分 & $213.6 \pm 12.6$ & 0.290 & $0.048^{*}$ \\
\hline 透析回数 & 回/週 & $2.81 \pm 0.12$ & 0.157 & 0.293 \\
\hline 透析前 BUN & $\mathrm{mg} / \mathrm{dL}$ & $64.8 \pm 2.3$ & 0.014 & 0.928 \\
\hline 透析後 BUN & $\mathrm{mg} / \mathrm{dL}$ & $26.3 \pm 2.1$ & -0.210 & 0.156 \\
\hline 透析前 Cr & $\mathrm{mg} / \mathrm{dL}$ & $8.03 \pm 0.33$ & -0.165 & 0.268 \\
\hline 透析後 $\mathrm{Cr}$ & $\mathrm{mg} / \mathrm{dL}$ & $3.67 \pm 0.23$ & -0.298 & $0.042^{*}$ \\
\hline 除水量 & L/回 & $1.85 \pm 0.13$ & 0.195 & 0.190 \\
\hline 血流量 & $\mathrm{mL} /$ 分 & $180.7 \pm 9.5$ & 0.084 & 0.574 \\
\hline 導入病院初診期間 & か月 & $19.0 \pm 8.1$ & 0.030 & 0.843 \\
\hline 導入時 eGFR & $\mathrm{mL} /$ 分 & $5.52 \pm 0.56$ & -0.004 & 0.978 \\
\hline 導入時臨床症状点数 & 点 & $17.7 \pm 2.4$ & 0.174 & 0.242 \\
\hline 導入時日常生活障害度点数 & 点 & $17.4 \pm 1.3$ & 0.115 & 0.443 \\
\hline 旧 厚生省研究班透析導入基準点数 & 点 & $66.7 \pm 3.3$ & 0.259 & 0.079 \\
\hline 導入原疾患（糖尿病率） & & $0.317 \pm 0.045$ & -0.174 & 0.241 \\
\hline \multicolumn{2}{|c|}{ 初回透析アクセス内シャント自己血管使用率 } & $0.858 \pm 0.053$ & -0.115 & 0.441 \\
\hline
\end{tabular}

医師に関しては専従の医師，一般医師数では予後に有 意な影響は与えなかったが透析専門医は 1 年生存率を 上昇させていた．また，夜間透析施設数，同時透析能 力, 最大収容能力, コンソール数が多い都道府県ほど 1 年生存率が上昇していた.

都道府県別専門医数と各種因子との関連では, 正の 相関を認めたのは, 透析導入患者数, 1 年生存率, 蛋白 異化率, $\mathrm{Kt} / \mathrm{V}, 1$ 回あたり透析時間, 透析施設数, 夜 間透析施設数であり，負の相関を認めたのは，透析後 Crであった，すなわち透析患者が多い地域には透析 施設・透析専門医が多数㧍り, 長時間透析を行い溶質 除去を充分行うことにより予後を改善していると考え
られる. Furumatsu ${ }^{16}$ は日本の透析専門医数が多 い地区では透析患者の長期予後が良いことを示した が, 今回の研究結果はこの報告の裏付けとなるもので ある。

今回のわれわれの透析導入後の研究では週 9,000 単 位以上エリスロポエチンを必要とする低反応例が多い 都道府県の予後が悪くなっていた. Furumatsu ら ${ }^{6}$ は 地域別の 6,000 単位以上のエリスロポエチンの販売量 を製薬会社より入手し検討を行っている. この研究で は保存期のエリスロポエチンの投与量が多い都道府県 ほど透析の導入率が低くなっていることが示された。 Usami $~^{55}$ は Ca 拮抗薬, ACE 阻害薬の地域別売上高 
の資料を製薬会社より入手し検討を行い，ACE 阻害 薬の消費量が少ない地域で透析導入率が高いことを報 告した。しかしながら医療機関受診率が高い都道府県 は医療機関での薬剤の販売量も増加してしまう可能性 がある。黑川 ${ }^{177}$ は塩分摂取量が多い地域で高血圧の患 者が多いことを示すために，国民栄養調査結果と，降 圧薬の販売量を比較している.この研究では降圧薬の 販売量だけでなく, 胃薬などのその他の薬剤の販売量 も同時に比較し, 塩分摂取量の多い地域は少ない地域 に比べ，降圧薬が他の薬剤よりも突出して多いことで それを証明した．地域別の薬剤の販売量の資料を使用 する際は, 慎重な判断が求められる.

毎年末に行われる日本透析医学会の調查回収率は全 透析施設数の $98 \%$ を超えている ${ }^{9}$. この回収率に都道 府県間で統計学的有意差はないが, 残りの $2 \%$ 足らず の施設にどのくらいの患者数がいるかは不明であり， サンプルの抽出の隔たりのなさを厳密に証明すること はできない。また今回の結果で透析導入率や予後に影 響を与えている因子は多数認められ，その地域差を解 消することで透析医療を改善できる余地があることを 示したが，逆に有意差が認められなかった項目がこれ らに影響を与えていないとはいえない。日本全体の解 析で透析導入率や予後に有意に影響を与える因子で あっても治療法や行政により標準的サービスが確立 し, 全国で均一となっている項目はデー夕の変動が小 さく統計学的に有意差が生じないこともある。すでに 糖尿病の有無と生命予後は密接に関係することが知ら れているが，今回透析導入原疾患（糖尿病率）と透析 導入後 1 年生存率が相関を認めていない.この結果も これらが要因である可能性がある。また実際に関連が あっても統計学的に有意差が出ないことも考えられ る. 気象の変動が患者に与える影響も生命科学的に因 果関係を証明することは困難である。背景となる交絡 因子の存在や, 地域相関研究では生態学的誤謬18 にも 注意が必要であり, 今後さらに詳細な検討が必要であ る.

\section{結 論}

透析患者の導入率，生存率にはさまざまな要因が関 与していると考えられ，今後の透析医療をいかに進め ていくかはさまざまな観点から検討していかなければ ならない。

\section{文献}

1) Collins A, Foley R, Herzog C, Chavers B, Gilbertson D,
Ishani A, Kasiske B, Liu J, Mau LW, McBean M, Murray A, St Peter W, Guo H, Li Q, Li S, Li S, Peng Y, Qiu Y, Roberts T, Skeans M, Snyder J, Solid C, Wang C, Weinhandl E, Zaun D, Arko C, Chen SC, Dalleska F, Daniels F, Dunning S, Ebben J, Frazier E, Hanzlik C, Johnson R, Sheets D, Wang X, Forrest B, Constantini E, Everson S, Eggers PW, Agodoa L : Excerpts from the United States Renal Data System 2009 annual data report : atlas of end-stage renal disease in the United States. Am J Kidney Dis 55 (Suppl 1) : S1-417, 2010

2) Ogata S, Yorioka N, Gilbertson DT, Chen SC, Foley $\mathrm{RN}$, Collins AJ : Genetic and environmental effects and characteristics of Japanese end-stage renal disease patients. Hemodial Int 13 (Suppl 1) : S8-12, 2009

3) Brookhart MA, Schneeweiss S, Avorn J, Bradbury BD, Rothman KJ, Fischer M, Mehta J, Winkelmayer WC : The effect of altitude on dosing and response to erythropoietin in ESRD. J Am Soc Nephrol 19 : 13891395, 2008

4) Winkelmayer WC, Liu J, Brookhart MA : Altitude and aii-cause mortality in incident dialysis patients. JAMA $301:$ 508-512, 2009

5) Usami T, Nakao N, Fukuda M, Takeuchi O, Kamiya Y, Yoshida A, Kimura G: Maps of end-stage renal disease and amounts of angiotensin-converting enzyme inhibitors prescribed in Japan. Kidney Int 64 : 1445-1449, 2003

6) Furumatsu $Y$, Nagasawa $Y$, Hamano $T$, Iwatani H, Shoji T, Ito T, Tsubakihara Y, Imai E : Integrated therapies including erythropoietin decrease the incidence of dialysis: lessons from mapping the incidence of end-stage renal disease in Japan. Nephrol Dial Transplant $23:$ 984-990, 2008

7）尾形 聡, 岩崎幸恵, 松田正裕, 森 雅弘, 松木 暁, 辰川自光, 賴岡德在 : 都道府県別透析導入患者生存率 に影響を与える因子について. 透析会誌 40 ：255-259, 2007

8）尾形 聡：糖尿病性腎症を原疾患とする新規透析導入 率の都道府県別栄養学的検討. 日腎会誌 $52: 934-938$, 2010

9）椿原美治：わが国の慢性透析療法の現況. 2008 年 12 月 31 日現在. CD-ROM. 日本透析医学会統計調查委 員会編, 東京, 2009

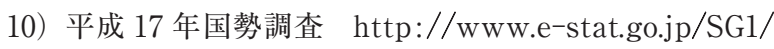
estat $/$ List.do?bid $=000001007609 \&$ cycode $=0$

11） http://www.jsdt.or.jp/html/specialist.html（2008 年 11 月検索)

12) 日本透析医学会：日本透析医学会施設会員名簿 2006 年度版. p1-233, 日本透析医学会, 東京, 2006

13）中村美詠子, 吉池信男, 田中平三: 国民栄養調查デー 夕を活用した都道府県栄養関連指標の検討。平成 14 
年度 厚生科学研究費補助金健康科学総合研究事業

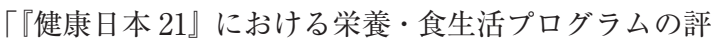
価手法に関する研究」p1-150, 2003 http://www.nih. go.jp/eiken/yousan/eiyochosa/index.html（2008 年 11 月検索)

14）財務省統計局：統計でみる都道府県のすがた（2008）. p1-195, 日本統計協会, 東京, 2008

15）日本透析医学会統計調査委員会 : わが国の慢性透析療 法の現況. 2001 年 12 月 31 日現在. CD-ROM. 日本 透析医学会, 東京, 2002
16) Furumatsu $Y$, Nagasawa $Y$, Yamamoto $R$, Iio $K$, Iwatani H, Matsui I, Takabatake Y, Kawada N, Shoji T, Imai E, Isaka Y, Rakugi $\mathrm{H}$ : Specialist care and improved long-term survival of dialysis patients. Nephrol Dial Transplant 25 : 1930-1935, 2010

17）黑川 清：食塩と高血圧. 日病態栄養会誌 5:1-6, 2001

18) http://www.med.osaka-u.ac.jp/pub/kid/clinicaljour nalclub13.html（2010 年 8 月検索） 